ADAM CZERNIAK*

Szkoła Główna Handlowa w Warszawie

PATRYCJA GRACA-GELERT**

Szkoła Główna Handlowa w Warszawie

RYSZARD ŁUCZYN***

Szkoła Główna Handlowa w Warszawie

https://doi.org/10.26485/PS/2018/67.2/1

\title{
PERCEPCJA NIERÓWNOŚCI DOCHODOWYCH A POPARCIE POLSKICH PARTII POLITYCZNYCH W LATACH 2007-2015
}

\section{Streszczenie}

W artykule został omówiony wpływ percepcji nierówności dochodowych na preferencje polityczne Polaków w latach 2007-2015. Badane były przy tym zarówno zmiany akceptacji nierówności dochodowych, jak też oceny zasadności podziału dochodu w społeczeństwie. Ocena wpływu tych zmian na preferencje polityczne, w tym zwłaszcza na poparcie partii opowiadających się za zwiększeniem redystrybucji dochodów przez państwo, została dokonana za pomocą analizy statystycznej na zagregowanych danych o poparciu partii politycznych oraz analizy ekonometrycznej mikrodanych z badań ankietowych. $Z$ przeprowadzonych obliczeń wynika, że percepcja nierówności dochodowych, a w szczególności ocena ich zasadności, stała się po globalnym kryzysie jedną z determinant decyzji wyborczych Polaków. Osoby oceniające nierówności dochodowe jako niezasadne i zbyt wysokie $\mathrm{z}$ większym prawdopodobieństwem głosowały na partie opowiadające się za redystrybucją dochodów.

Słowa kluczowe: wybory parlamentarne, percepcja nierówności dochodowych, partie polityczne

* Dr, e-mail: adam.czerniak@sgh.waw.pl

** Dr, e-mail: pgraca@sgh.waw.pl

*** Mgr, e-mail: r.luczyn@politykainsight.pl 


\section{WSTĘP}

Wynik wyborów parlamentarnych z 2015 roku, czyli uzyskanie samodzielnej większości w Sejmie przez Prawo i Sprawiedliwość (PiS), stanowił zaskoczenie zarówno dla liderów politycznych, jak i dla politologów, ekonomistów czy socjologów. Przyczyn tego fenomenu opisano już wiele - od wybuchu kryzysu migracyjnego [Starzyk 2016] przez zmęczenie ówczesnym rządem aż po „prezydencjalizację" wyborów parlamentarnych [Peszyński 2016] i niekorzystną dla Zjednoczonej Lewicy ordynację wyborczą. Najbardziej zaskakujące, zwłaszcza dla polityków partii koalicyjnych Platformy Obywatelskiej (PO) i Polskiego Stronnictwa Ludowego (PSL), było jednak wysokie poparcie obywateli dla redystrybucyjnych elementów programu gospodarczego PiS [Miernik 2018], w tym propozycji wypłat świadczeń wychowawczych, podniesienia kwoty wolnej od podatku czy obniżenia wieku emerytalnego. Ich niezrozumienie wynikało z faktu, że w okresie rządów PO-PSL odnotowano w Polsce największy wzrost gospodarczy w całej Unii Europejskiej, szybki wzrost realnych płac, najniższy od początku transformacji systemowej poziom stopy bezrobocia oraz stabilne (lub jak wskazywały niektóre wskaźniki, nawet malejące) nierówności dochodowe w społeczeństwie [Graca-Gelert 2016]. Takie dane statystyczne utrzymywały rząd PO-PSL w błędnym przekonaniu, że ludzie doceniają odnotowany w latach 2007-2015 wzrost stopy życia i nie zagłosują na inne partie ze względu na formułowane przez nie propozycje reform nakierowanych na zwiększenie redystrybucji dochodów.

Niniejszy artykuł skupia się właśnie na tym wymiarze zmian w poparciu politycznym. Jego celem jest zbadanie, czy dostępne dane empiryczne potwierdzają, że zmiana percepcji nierówności dochodowych, jaka dokonała się w ostatniej dekadzie, była istotnym statystycznie czynnikiem wzrostu poparcia społecznego dla tych partii politycznych, które opowiadają się za zwiększeniem redystrybucji dochodów w Polsce.

W pierwszej części omówiono sposób pomiaru i zmiany percepcji nierówności dochodowych w Polsce, szczególną uwagę zwracając na okres po globalnym kryzysie ekonomicznym, czyli w latach 2010-2015. Skupiono się w nim na przeprowadzeniu analizy zmian percepcji nierówności dochodowych w Polsce w czterech wymiarach - według dochodu, wieku, poziomu wykształcenia oraz miejsca zamieszkania. W drugiej części omówiono natomiast szczegółowo wahania poparcia dla głównych partii politycznych między wyborami parlamentarnymi z 2007, 2011 i 2015 roku w rozbiciu na te cztery wymiary. Arbitralnie wydzielono przy tym te partie, które kładły duży nacisk na redystrybucję dochodów jako 
element programu wyborczego. Na koniec sprawdzono za pomocą estymacji ekonometrycznej, czy i w jakim stopniu poparcie konkretnej partii politycznej zależy od percepcji nierówności dochodowych. W podsumowaniu zakreślono natomiast implikacje otrzymanych wyników i wskazano potencjalny kierunek dalszych przemian na polskiej scenie politycznej.

\section{PERCEPCJA NIERÓWNOŚCI DOCHODOWYCH PO 1989 ROKU W POLSCE}

W literaturze empirycznej istnieją dwa główne podejścia do terminu „percepcja nierówności dochodowych" ocenę skali nierówności dochodowych w otoczeniu społeczno-gospodarczym badanej populacji [Niehues 2014; Engelhardt, Wagener 2014], co oznacza, że ocenie poddane jest to, jak bardzo nierówny jest rozkład dochodów w społeczeństwie. Drugie rozumienie terminu ,percepcja nierówności dochodowych” [Alesina, Di Tella, MacCulloch 2004; Schneider 2012] dotyczy tego, w jaki sposób ludzie oceniają różnice w dochodach, których doświadczają w swoim otoczeniu gospodarczym, tj. czy uznają je za uzasadnione, czy je akceptują i czy uważają, że należy je zmienić. $Z$ punktu widzenia naszego badania bardziej interesujące jest to drugie podejście, zwłaszcza że implicite uwzględnia też subiektywną ocenę skali nierówności dochodowych.

W ramach tego podejścia do percepcji nierówności dochodowych istotne jest dokonanie kolejnego rozróżnienia - na akceptację różnic w dochodach w społeczeństwie oraz na postrzeganie zasadności tych różnic. Akceptacja nierówności jest ściśle związana z preferencjami ludzi względem redystrybucji dochodów. Opisuje, w jakim stopniu chcą oni zmniejszyć nierówności i jak duże znaczenie ma dla nich przeciwdziałanie ubóstwu w ich społeczeństwie. Jeśli ludzie akceptują nierówności, to znaczy, że są zadowoleni z (postrzeganego przez siebie) poziomu różnic w dochodach w ich otoczeniu społeczno-gospodarczym. W niektórych przypadkach ludzie mogą nawet wymagać wyższych różnic w dochodach - nie tylko akceptują obecny poziom nierówności, ale chcą jeszcze większego zróżnicowania dochodów w celu stworzenia systemu zachęt do cięższej pracy lub uczynienia z niego bardziej precyzyjnego wyróżnika przynależności do poszczególnych klas społecznych. Subiektywna ocena zasadności podziału dochodów

I W tym miejscu pominięto teoretyczne rozważania nad percepcją nierówności dochodów, w tym także awersją do nich, która bywa uwzględniana w funkcjach dobrobytu społecznego. Przykładem zastosowania takiej funkcji jest np. miernik nierówności Atkinsona. 
mówi z kolei o tym, jak ludzie oceniają nierówności. Czy uważają, że wyższe zarobki są zwykle efektem ciężkiej pracy, czy też szczęścia, koneksji lub nieetycznych zachowań, takich jak dawanie łapówek lub utrzymywanie stosunków seksualnych w zamian za uzyskanie lepiej płatnej pracy.

Literatura na temat percepcji nierówności dochodowych jest dosyć bogata i nie brakuje w niej badań dotyczących percepcji zróżnicowania dochodów w Polsce. Z uwagi na złożoność problematyki percepcji nierówności studia na ten temat nie wyczerpuja jednak tego obszaru badawczego, a różnorodność wykorzystanych do pomiaru percepcji nierówności dochodowych danych ${ }^{2}$ prowadzi do niskiej porównywalności wyników w czasie i między poszczególnymi badanymi grupami społecznymi, a w skrajnych przypadkach nawet do sprzecznych odpowiedzi na te same pytania badawcze. Mimo to przegląd tych badań pozwala na zaprezentowanie kilku zaobserwowanych przez badaczy prawidłowości.

Podstawowy wniosek na temat percepcji nierówności dochodów w Polsce w ostatnim ćwierćwieczu jest taki, że stopniowo zwiększa się odsetek osób oceniających zróżnicowanie dochodowe jako zbyt duże [np. Domański, Sawiński 2012; Karpiński 2010; Brzeziński, Jancewicz, Letki 2013]. Jednocześnie dane na temat percepcji nierówności wynagrodzeń wskazują, że Polacy dostosowywali akceptację rozpiętości zarobków (jak powinno być) do rosnącej oceny poziomu nierówności wynagrodzeń (jak jest), przy czym ocena poziomu nierówności wynagrodzeń wzrastała szybciej niż ich akceptowany poziom [np. Domański, Sawiński 2012; Kołczyńska, Merry 2013]. Z niektórych badań wynika, że mniej więcej w połowie lat 90 . trend rosnącej akceptacji nierówności w niektórych ich aspektach odwrócił się [np. Grosfeld, Senik 2010; Karpiński 2010; Wysieńska-Di Carlo, Di Carlo 2014; Kołczyńska, Merry 2013; Kelley, Zagórski 2003].

Powyżej opisane badania nie dostarczyły jednak wystarczającego materiału empirycznego do porównania zmian percepcji nierówności dochodowych w ostatniej dekadzie, zwłaszcza w kluczowych z punktu widzenia niniejszego badania wymiarach - poziomu wykształcenia, dochodu czy miejsca zamieszkania. W związku z powyższym skorzystaliśmy z analizy przemian percepcji nierówności dochodowych w Polsce opisanych szczegółowo w pracy Czerniaka i Gracy-Gelert [2017]. W badaniu tym wykorzystano dane World Values Survey (WVS), które dostarczają odpowiedzi na kilka standardowych pytań dotyczących

2 Najczęściej wykorzystywanymi źródłami danych w tych badaniach są dane z Polskiego Badania Panelowego (POLPAN), ISSP (International Social Survey Programme), względnie PGSS (Polski Generalny Sondaż Społeczny) oraz WVS (World Values Survey) czy ESS (European Social Survey). 
postaw wobec nierówności dochodowych i ciężkiej pracy. O wyborze danych WVS zadecydowało, że równocześnie spełniają one kilka niezbędnych do przeprowadzenia niniejszej analizy wymagań. Po pierwsze, WVS jest badaniem cyklicznym, w ramach którego te same pytania zadawane są od ponad 35 lat, co umożliwia osadzenie analizy ostatnich zmian percepcji nierówności dochodowych w szerszym kontekście. Dzięki temu możliwa jest ocena, czy zmiany, które zaszły w Polsce od 2005 roku, wpisują się w długookresowy trend, czy też stanowią precedens na tle przemian w postawach Polaków po transformacji ustrojowej. Po drugie, badanie WVS ma bardzo liczną próbę i w każdej z fal uczestniczy blisko 1000 respondentów z Polski. Po trzecie, w badaniu WVS zawarte są zarówno pytania o preferencje polityczne, jak i pytania, które mogą stanowić przybliżony miernik akceptacji i oceny zasadności nierówności dochodowych w Polsce. Po czwarte, niniejsze opracowanie jest częścią szerszego programu badawczego, w ramach którego porównywane są zmiany percepcji nierówności dochodowych na świecie oraz analizowany jest ich wpływ na aktywność gospodarczą i społeczną [Czerniak, Graca-Gelert, 2016]. Tego typu analiza możliwa jest wyłącznie przy wykorzystaniu danych WVS.

Niestety w ankietach WVS żaden z analizowanych wymiarów percepcji nierówności dochodowych nie był bezpośrednio przedmiotem jakiegokolwiek z pytań, dlatego konieczne było zastosowanie miar przybliżonych, które w jak największym stopniu odzwierciedlają omawiane preferencje społeczne. W związku z tym jako miernik akceptacji nierówności użyto wyniki odpowiedzi na pytanie numer E035: czy respondenci żądają bardziej równych dochodów (odpowiedź $1 \mathrm{w}$ skali 1-10), czy też dochody powinny w większym stopniu nagradzać indywidualny wysiłek (odpowiedź 10)? Tego typu lub zbliżone pytania są zadawane w większości badań ankietowych, w których poruszana jest kwestia percepcji nierówności dochodowych (m.in. ESS, EVS, CBOS), a zatem jego zastosowanie w niniejszej analizie nie powinno budzić zastrzeżeń. Wątpliwości może jedynie rodzić zestawienie ze sobą dwóch nie w pełni rozłącznych twierdzeń, czyli „różnice w dochodach powinny być mniejsze” $i$, „ochody powinny w większym stopniu nagradzać indywidualny wysiłek". Można sobie bowiem wyobrazić, że część respondentów sądzi, że należy równocześnie zmniejszyć nierówności dochodowe i zwiększyć stopień, w jakim nagradzają indywidualny wysiłek. Tego typu poglądy zapewne są jednak rzadkością, a jeżeli już w społeczeństwie istnieją to obciążają przede wszystkim poziom tego miernika, a nie jego zmiany w czasie, które są przedmiotem analizy. 
Ponieważ w żadnej znanej autorom ankiecie nie pytano respondentów bezpośrednio o ocenę zasadności nierówności dochodowych, zdecydowano się wykorzystać w analizie odpowiedzi na pytanie numer E040: w jakim stopniu respondenci zgadzają się ze zdaniem, że na dłuższą metę ciężka praca zapewnia lepsze życie (odpowiedź $10 \mathrm{w}$ skali $1-10)^{3}$, a w jakim stopniu, że ciężka praca na ogół nie gwarantuje sukcesu, który jest raczej kwestią szczęścia i znajomości (odpowiedź 1)? Przyjęcie takiego miernika może rodzić zastrzeżenia, ponieważ może on odzwierciedlać percepcję korupcji czy wręcz skalę rozpowszechnienia nepotyzmu, a nie niską zasadność zróżnicowania dochodów w rozumieniu ekonomicznym. Rozróżnienie tych dwóch podejść jest jednak kluczowe z punktu widzenia celów niniejszego badania, ponieważ percepcja korupcji władzy jest ściśle powiązana z preferencjami politycznymi, zwłaszcza w Polsce [Jasiecki 2010]. Dlatego przeprowadzono badanie korelacji powyższego miernika z odpowiedziami na dwa pytania zadane tylko w ramach ankiety WVS z 1997 roku, które dotyczą kwestii oceny zasadności nierówności dochodowych, ale już w ich stricte ekonomicznym sensie. Pierwsze z nich (pyt. E131) mierzy, jaka część populacji uważa, że ludzie są biedni z powodu niesprawiedliwego społeczeństwa (co koresponduje z poglądem, że nierówności dochodowe są nieuzasadnione), a jaka część populacji uważa, że ludzie są biedni z powodu własnego lenistwa (co koresponduje z poglądem, że nierówności dochodowe są zasadne). Odpowiedzi na drugie pytanie (E132) pokazująz kolei, jaka część respondentów uznaje, że osoby biedne mają nikłe szanse wyrwać się z ubóstwa, czyli ich niskie dochody nie są uzasadnione aktywnością ekonomiczną, umiejętnościami czy kompetencjami. Z przeprowadzonych obliczeń wynika, że odpowiedzi respondentów na pytania E040 oraz E131 i E132 są ze sobą istotnie statystycznie skorelowane (przy poziomie istotności odpowiednio 10\% i 1\%), co stanowi mocną przesłankę na rzecz przyjęcia odpowiedzi na pytanie E040 jako dobrego (choć wciąż może być on obarczony znacznym błędem) miernika oceny zasadności nierówności dochodowych w społeczeństwie.

Mimo ograniczeń i niskiej precyzji powyższych mierników zdecydowano się - ze względu na brak lepszej alternatywy - na wykorzystanie ich w dalszej części analizy. Korzyści z możliwości przeprowadzenia badania na powtarzalnych pytaniach zadanych odpowiednio wysokiej próbie przewyższają bowiem koszty

W porównaniu z oryginalnym badaniem dokonaliśmy transformacji zmiennej, odwracając skalę. W badaniu WVS odpowiedź 10 oznaczała, że ciężka praca na ogół nie przynosi sukcesu, a odpowiedź 1 oznaczała, że ciężka praca zapewnia lepsze życie. Zmiana była podyktowana chęcią zwiększenia przejrzystości wywodu. 
związane z niedokładnością pomiaru percepcji nierówności dochodowych. Co więcej, wybór pytań E035 i E040 ma jeszcze jedną zaletę. Uwzględniono je we wszystkich czterech falach badania WVS, tj. przeprowadzonych w latach 1989, 1997, 2005 i 2012, co umożliwia zbadanie trendów zmian percepcji nierówności dochodowych od czasów transformacji. By odformalizować opis analizowanych zmiennych, od tego miejsca nazwano E035 miarą akceptacji, a E040 miarą zasadności nierówności dochodów.

W celu porównania rozkładów odpowiedzi na powyższe pytania w poszczególnych latach oraz według wieku, dochodu, poziomu wykształcenia i miejsca zamieszkania ${ }^{4}$ wyliczono średnie i odchylenia standardowe badanej próby. $\mathrm{Na}$ tej podstawie określono, czy różnice pomiędzy średnimi odpowiedziami na oba pytania dla poszczególnych lat i poszczególnych zmiennych kontrolnych są od siebie statystycznie istotnie różne 5 .

Analizę rozpoczyna przedstawienie tendencji średnich akceptacji i zasadności nierówności dochodowych na tle rzeczywistego poziomu zróżnicowania dochodów mierzonego za pomocą współczynnika Giniego w Polsce w okresie 1989-2012 (rysunek 1). Z uwagi na brak dostępności spójnego szeregu czasowego ostatniej zmiennej pokazano dane pochodzące z trzech źródeł, które mimo że różnią się od siebie pod względem metody badawczej, dają pewien obraz zmian nierówności dochodów w badanym okresie.

4 W niniejszym badaniu autorzy skupili się przede wszystkim na tych zmiennych, które najczęściej występują w analizach empirycznych dotyczących percepcji nierówności dochodowych. Są to także najczęściej stosowane zmienne socjodemograficzne, występujące w badaniach wyborczych [Cześnik 2014], a także jedyne uwzględniane w badaniach preferencji politycznych w okresie wyborów (np. CBOS). Z tego względu nie mogliśmy wykorzystać bardziej zaawansowanych zmiennych, jak np. samoocena sytuacji finansowej gospodarstwa domowego. Jedynym wyjątkiem jest analiza percepcji nierówności dochodowych ze względu na płeć. Pominięto ją, bo akceptacja oraz ocena zasadności nierówności dochodów wśród kobiet i mężczyzn była bardzo podobna i nie obserwowano istotnych różnic między płciami w czasie. Należy jednak podkreślić, że kobiety uznawały zróżnicowanie dochodów za istotnie mniej zasadne niż mężczyźni [Czerniak, Graca-Gelert 2017].

5 Wykorzystaliśmy do tego test $\mathrm{t}$ równości średnich dla prób niezależnych. Zastosowanie tego testu było możliwe ze względu na dużą liczbę dostępnych obserwacji (N>100), inny zbiór respondentów w obu próbach i pomiar tej samej cechy, co umożliwiło przyjęcie założenia o równości wariancji w obu populacjach. Na zasadność tego założenia wskazują też przeprowadzone testy równości wariancji. 
RYSUNEK 1. Nierówności dochodowe ${ }^{\mathrm{a}} \mathrm{a}$ ich percepcja ${ }^{\mathrm{b}} \mathrm{w}$ Polsce w latach 1989-2012

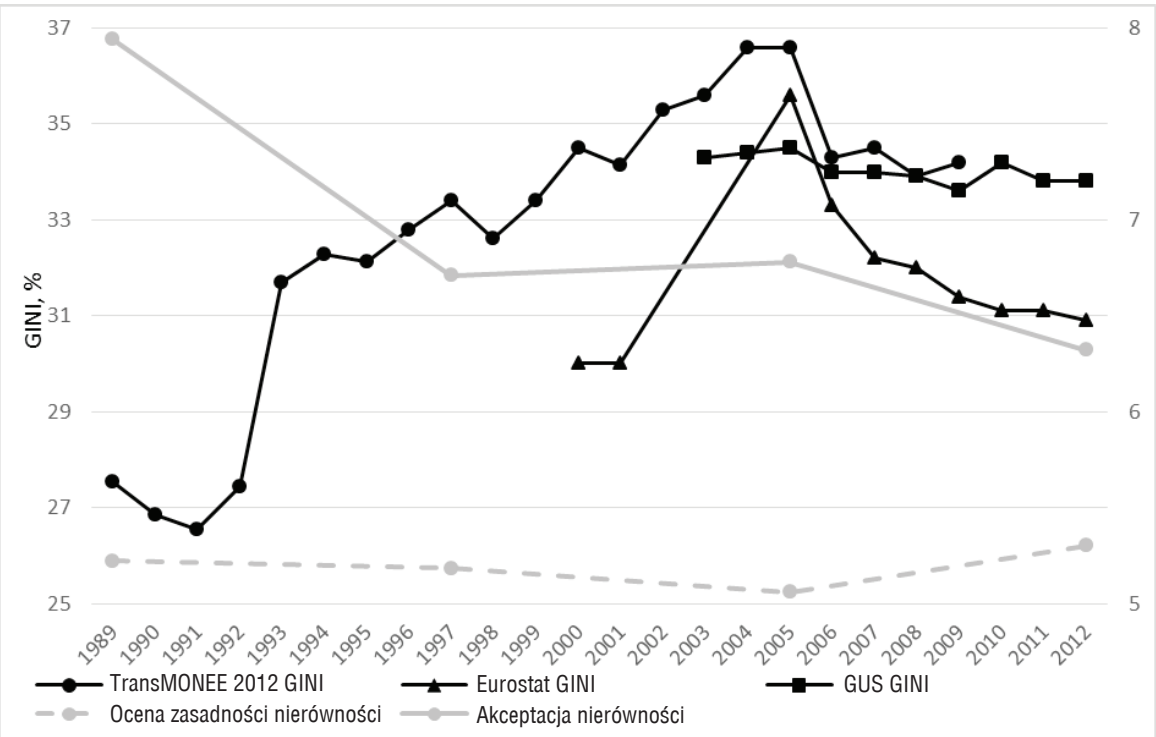

a TransMONEE - dochód do dyspozycji gospodarstw domowych per capita; Eurostat - dochód do dyspozycji gospodarstw domowych w przeliczeniu na jednostkę ekwiwalentną (jednostka odniesienia to osoba); GUS - dochód rozporządzalny gospodarstw domowych per capita.

b „Akceptacja nierówności”: 1 - rozpiętość dochodów należy zmniejszyć; 10 - dochody powinny w większym stopniu nagradzać indywidualny wysiłek. „Zasadność nierówności”: 1 - ciężka praca na ogół nie przynosi sukcesu, który jest raczej kwestią szczęścia i znajomości; 10 - ciężka praca stanowi źródło sukcesu.

Źródło: GUS 2017, Tabl. 5: 299; Eurostat; TransMONEE 2012 Database, UNICEF Regional Office for CEE/CIS, Geneva; opracowanie własne na podstawie danych WVS.

Poza początkiem lat 90., kiedy to doszło do pewnego spadku rozpiętości dochodów, nierówności w Polsce wzrastały niemal nieprzerwanie mniej więcej do momentu rozszerzenia Unii Europejskiej, a następnie zaczęły maleć lub (w zależności od badania) fluktuować dookoła stabilnego poziomu. Z kolei akceptacja nierówności dochodowych silnie zmalała między rokiem 1989 a 1997, między 1997 a 2005 nie wystąiła żadna istotna statystycznie zmiana tej oceny, natomiast po globalnym kryzysie finansowym można zauważyć dalszy spadek akceptacji nierówności dochodowych, choć w nieco mniejszej skali niż w latach $90^{6}$. W przypadku oceny zasadności nierówności dochodowych liczba

6 Podobne zmiany akceptacji nierówności można zauważyć w innych źródłach danych, np. POLPAN czy CBOS [CBOS 2017]. 
respondentów deklarujących, że ciężka praca stanowi źródło sukcesu zmalała między 1997 a 2005 rokiem, a następnie wzrosła w 2012, i to nieco powyżej poziomu z początku transformacji. Różnice pomiędzy poszczególnymi latami były jednak statystycznie mniej istotne niż w przypadku zmian akceptacji nierówności dochodowych.

Powyższa analiza wskazuje, że pomimo stabilizacji lub nawet spadku faktycznych nierówności dochodowych po globalnym kryzysie finansowym w społeczeństwie wzrosło przekonanie, że nierówności te powinny być zmniejszane, przy jednoczesnym wzroście przeświadczenia, że faktyczny wysiłek wkładany przez ludzi w pracę stanowi źródło ich sukcesu. Stanowi to przesłankę na rzecz hipotezy badawczej, że w ostatnich latach rządów PO-PSL znacząco wzrosło zapotrzebowanie społeczne na redystrybucję dochodów, zwłaszcza w stosunku do osób, które zostały wykluczone z korzyści, jakie przyniósł najszybszy w Unii wzrost gospodarczy. Najprawdopodobniej wzrost dochodów osób pracujących uświadomił części społeczeństwa, że ciężka praca przynosi sukces, ale sukces ten jest dostępny wyłącznie osobom pracującym, co powoduje wykluczenie z grona beneficjentów wzrostu gospodarczego pozostałych grup społecznych, zwłaszcza tych niepracujących. Poniżej przeanalizowano, czy zmiany w percepcji nierówności dochodowych między 2005 a 2012 rokiem rozkładały się równomiernie wśród wszystkich Polaków, czy nastapiły wyłącznie w poszczególnych grupach społeczno-ekonomicznych, klasyfikowanych według wieku, dochodu, wykształcenia i miejsca zamieszkania (por. tabela 1).

Akceptacja nierówności dochodowych spadła między 2005 a 2012 rokiem we wszystkich grupach wiekowych, przy czym spadek ten był istotny statystycznie jedynie wśród osób w średnim wieku (kohorta 45-54 lata). Co ciekawe, w 2012 roku grupą najczęściej domagającą się zmniejszenia nierówności dochodowych byli seniorzy (kohorta 65 i więcej lat), podczas gdy na początku transformacji osoby najstarsze najbardziej je akceptowały, $i$ to nawet $w$ większym stopniu niż osoby młode. Wiek jest także zmienną silnie różnicującą zmiany zasadności nierówności w czasie. Wpływ na to mają jednak wyłącznie dwie kohorty: osoby w wieku 25-34 lat i 35-44 lat. W obu tych grupach silnie wzrosło przeświadczenie, że ciężka praca przynosi sukces, przy czym w młodszej z obu kohort przekonanie to było najwyższe w porównaniu z resztą społeczeństwa. W pozostałych grupach nie odnotowano większych zmian w latach 2005-2012, a wśród osób najstarszych odczucia co do tego, że nierówności dochodowe są zasadne, nawet nieznacznie się osłabiły. Zmiana ta nie była jednak istotna statystycznie. 
TABELA 1. Zmiany percepcji nierówności dochodowych ${ }^{\mathrm{a}}$ w Polsce w latach 2005-2012 według poszczególnych grup społeczno-ekonomicznych

\begin{tabular}{|c|c|c|c|c|c|c|}
\hline & \multicolumn{3}{|c|}{$\begin{array}{l}\text { Akceptacja nierówności } \\
\text { dochodowych }\end{array}$} & \multicolumn{3}{|c|}{$\begin{array}{c}\text { Ocena zasadności } \\
\text { nierówności dochodowych }\end{array}$} \\
\hline & 2005 & 2012 & $\begin{array}{l}\text { Istotnośćc } \\
\text { statystyczna } \\
\text { różnicy }\end{array}$ & 2005 & 2012 & $\begin{array}{c}\text { Istotność } \\
\text { statystyczna } \\
\text { różnicy }\end{array}$ \\
\hline Ogólem & 6,78 & 6,32 & $0,000 * * *$ & 5,06 & 5,30 & $0,061 *$ \\
\hline \multicolumn{7}{|l|}{ wiek } \\
\hline 15-24 lata & 6,88 & 6,64 & 0,389 & 5,60 & 5,79 & 0,563 \\
\hline 25-34 lata & 6,99 & 6,57 & 0,151 & 5,19 & 6,00 & $0,009 * * *$ \\
\hline 35-44 lata & 6,74 & 6,24 & 0,118 & 4,61 & 5,60 & $0,002 * * *$ \\
\hline 45-54 lata & 6,71 & 6,13 & $0,059^{*}$ & 4,82 & 4,88 & 0,813 \\
\hline 55-64 lata & 6,75 & 6,36 & 0,236 & 4,96 & 4,95 & 0,980 \\
\hline $65+$ lat & 6,65 & 6,12 & 0,140 & 5,24 & 4,92 & 0,326 \\
\hline \multicolumn{7}{|l|}{ dochód } \\
\hline 1-4 grupa decylowa rozkładu & 6,59 & 6,15 & $0,022 * *$ & 4,72 & 4,99 & 0,156 \\
\hline 5-10 grupa decylowa rozkładu & 7,10 & 6,44 & $0,000 * * *$ & 5,49 & 5,57 & 0,636 \\
\hline \multicolumn{7}{|l|}{ wyksztalcenie } \\
\hline niskie & 6,54 & 6,43 & 0,618 & 5,09 & 5,08 & 0,970 \\
\hline średnie & 7,03 & 6,17 & $0,000 * * *$ & 4,96 & 5,23 & 0,185 \\
\hline wyższe & 7,05 & 6,39 & $0,019 * *$ & 5,20 & 5,77 & $0,045 * *$ \\
\hline \multicolumn{7}{|l|}{ miejsce zamieszkania } \\
\hline tereny wiejskie & 6,98 & 6,40 & $0,008 * * *$ & \multirow[b]{2}{*}{5,14} & \multirow[b]{2}{*}{5,35} & \multirow[b]{2}{*}{0,260} \\
\hline $\begin{array}{l}\text { małe miasta } \\
(2-20 \text { tys. mieszkańców) }\end{array}$ & 6,20 & 5,81 & 0,311 & & & \\
\hline $\begin{array}{l}\text { średnie i duże miasta } \\
(>20 \text { tys. mieszkańców) }\end{array}$ & 6,84 & 6,38 & $0,009 * * *$ & 4,99 & 5,26 & 0,132 \\
\hline
\end{tabular}

a „Akceptacja nierówności”: 1 - rozpiętość dochodów należy zmniejszyć; 10 - dochody powinny w większym stopniu nagradzać indywidualny wysiłek.

b „Zasadności nierówności”: 1 - ciężka praca na ogół nie przynosi sukcesu, który jest raczej kwestią szczęścia i znajomości; 10 - ciężka praca stanowi źródło sukcesu.

Gwiazdkami oznaczono te różnice w średnich, które są istotne statystycznie przy poziomie istotności: * $10 \%, * * 5 \%$ i *** $1 \%$ zgodnie z wynikami testów t dla prób niezależnych.

Źródło: opracowanie własne na podstawie danych WVS. 
Zmiany akceptacji zróżnicowania dochodów nie różniły się między grupami dochodowymi. Ze względu na silnie asymetryczny rozkład dochodów respondentów (i związany z tym niedobór respondentów w wyższych grupach decylowych) bardziej wiarygodne jest analizowanie zmian akceptacji nierówności ze względu na dwie grupy dochodowe - do i od 4. decyla rozkładu dochodów. W obu tych grupach akceptacja nierówności zmalała, przy czym nieznacznie mocniej wśród osób o wyższych dochodach. Różnice pomiędzy obiema grupami były jednak na tyle słabe, że akceptacja nierówności dochodowych pozostała (z oczywistych względów) mniejsza wśród osób o niższych dochodach. Również zmiany oceny zasadności nierówności dochodowych nie różniły się istotnie wśród osób z niższych i z wyższych grup decylowych rozkładu. Ciekawe jest to, że obie grupy nie różniły się postrzeganiem zasadności nierówności w 1989 roku, natomiast w kolejnych latach była ona przeciętnie zawsze wyższa w przypadku respondentów o wyższych dochodach.

Najciekawsze zmiany w percepcji nierówności dochodowych zaszły jednak ze względu na wykształcenie. U osób z wykształceniem podstawowym akceptacja zróżnicowania dochodów nie zmieniała się istotnie od lat 90., w tym także w latach pokryzysowych. Zmiany zachodziły za to w pozostałych grupach. Respondenci z wykształceniem średnim mieli dość stałe przekonania dotyczące potrzeby zmiany nierówności w latach 90 . i wczesnych dwutysięcznych, po czym doszło do istotnej zmiany poglądów na korzyść potrzeby zmniejszania nierówności dochodowych po globalnym kryzysie. W rezultacie to właśnie ta grupa okazała się w 2012 roku najmniej akceptować nierówności dochodowe i najbardziej domagać się ich zmniejszenia. W przypadku osób z wyższym wykształceniem między 2005 a 2012 rokiem akceptacja nierówności dochodowych również spadła, ale spadek ten był mniejszy i stanowił kontynuację trendu obserwowanego od lat 90. Podobnie jak w przypadku akceptacji nierówności poglądy związane z zasadnością zróżnicowania dochodów w Polsce pozostawały względnie stabilne wśród osób z niższym wykształceniem. W pozostałych grupach nastąpił wzrost odsetka osób wysoko oceniających zasadność nierówności dochodowych, przy czym wzrost ten był istotny statystycznie jedynie wśród osób z wyższym wykształceniem. Co ciekawe, w obu grupach nastapił powrót do poziomów obserwowanych w latach 90 .

$\mathrm{Z}$ analizy danych o akceptacji nierówności dochodowych wynika, że spadła ona między 2005 a 2012 rokiem niezależnie od wielkości miejsca zamieszkania respondenta, przy czym spadek ten był nieistotny statystycznie w przypadku małych miast (2-20 tys. mieszkańców), a istotny wśród osób zamieszkujących 
tereny wiejskie oraz średnie i duże miasta (pow. 20 tys. mieszkańców). Co ciekawe, w małych miastach nierówności dochodowe były najmniej akceptowane, a na terenach wiejskich i w większych miastach były akceptowane w podobnym stopniu. W przypadku analizy zmian oceny zasadności nierówności dochodowych połączono obserwacje dla małych miast $i$ terenów wiejskich ze względu na niedobór liczby respondentów oraz brak statystycznie istotnych różnic $\mathrm{w}$ odpowiedzi na pytanie E040 w obu tych grupach. Nawet jednak w takim podziale nie zaobserwowano znacznych różnic w zmianach oceny zasadności nierówności - w obu klasach miejscowości nastąpił wzrost przekonania, że ciężka praca stanowi źródło sukcesu, przy czym wzrost ten nie był istotny statystycznie w żadnej z grup.

Powyższa analiza pokazuje, że zmiany percepcji nierówności dochodowych różniły się istotnie przede wszystkim ze względu na wiek i poziom wykształcenia. $\mathrm{W}$ pozostałych analizowanych wymiarach różnice między grupami społecznymi nie były zbyt wyraźne. Zaskakujące jest, że zmiany percepcji nierówności dochodowych nastapiły w podobnym zakresie $\mathrm{w}$ grupach o niższych i wyższych dochodach, co sugeruje, że status majątkowy nie był decydujący przy zmianach poglądów po globalnym kryzysie.

\section{ZMIANY POPARCIA PARTII POLITYCZNYCH W WYBORACH PARLAMENTARNYCH W LATACH 2007-2015 NA TLE ZMIAN PERCEPCJI NIERÓWNOŚCI DOCHODOWYCH}

Badanie zmian poparcia partii politycznych według różnych wymiarów (wiek, dochód, miejsce zamieszkania, wykształcenie) wymaga sięgnięcia do badań ankietowych, bowiem z oczywistych względów w oficjalnych rejestrach Państwowej Komisji Wyborczej (PKW) takie dane nie są dostępne. Istnieją trzy źródła danych na temat poparcia partii w okresie wyborczym - wyniki badań typu exit poll, Polskie Generalne Studium Wyborcze (PGSW) oraz comiesięczne badania preferencji wyborczych Centrum Badań Opinii Społecznej (CBOS). Wykorzystanie każdego z tych zbiorów danych ma swoje wady i zalety.

Największą zaletą badań typu exit poll jest duża próba badawcza oraz największa wiarygodność odpowiedzi ankietowanych. Ich wadą, praktycznie uniemożliwiającą wykorzystanie w niniejszym badaniu, jest brak spójnych między panelami badań zmiennych krzyżowych, w tym podziału ze względu na wysokość dochodu czy klasę miejscowości zamieszkania. Z kolei PGSW, choć ma wysoką próbę badawczą i bardzo wiele zmiennych kontrolnych, jest nieadekwatnym źródłem danych dla niniejszego badania ze względu na komercyjny charakter ankiety z 2015 roku - jej wyniki nie są udostępniane na potrzeby badań naukowych. 
W rezultacie jedynym możliwym do wykorzystania w analizie źródłem danych są badania CBOS, i chociaż otrzymane na ich podstawie wyniki wyborcze różnią się od tych oficjalnych, to skala błędu jest zbliżona do tej otrzymywanej przy analizie danych z pozostałych źródeł, co wskazuje na jej losowy charakter i nie powinno prowadzić do systematycznych błędów w analizie szeregu czasowego. Mimo to, ze względu na chęć obniżenia obciążeń wynikających z niskiej liczebności próby, zamiast danych z jednego sondażu CBOS posłużono się średnimi z trzech ankiet: z miesiąca przed wyborami, z miesiąca wyborów i z miesiąca po nich?

Aby zbadać zmiany poparcia dla partii, które mogłyby wynikać ze zmian w percepcji nierówności dochodowych, zdecydowano się na analizę łącznego poparcia dla wszystkich ugrupowań, które za podstawowe punkty swojego programu wyborczego uznały propozycje związane ze zwiększeniem redystrybucji dochodów w społeczeństwie. Dzięki temu ograniczono wpływ innych czynników determinujących decyzje wyborcze Polaków, zwłaszcza tych niezwiązanych ze zmianami poparcia dla określonych punktów programu wyborczego. Za partie redystrybucyjne uznano więc te opowiadające się za progresywnym systemem podatkowym (np. podniesienie kwoty wolnej od podatku dla najmniej zarabiających, wprowadzenie trzeciego progu podatkowego), wyższymi transferami socjalnymi (np. świadczenia wychowawcze, niższy wiek emerytalny) czy za większą rolą państwa na rynku dóbr i usług (np. darmowe leki, mieszkania budowane przez państwo etc.). Warto przy tym zauważyć, że konkretne rozwiązania proponowane przez partie redystrybucyjne mogą się różnić nawet w znaczący sposób, jednak odwołują się one do wspólnej idei zwiększania strumienia transferów i wsparcia dla osób biedniejszych.

Ugrupowania liczące się na scenie politycznej ${ }^{8} \mathrm{w}$ latach 2007-2015, które opowiadały się za zwiększeniem redystrybucji dochodów, to: Partia Razem, Sojusz Lewicy Demokratycznej (SLD, w tym w 2007 roku jako Lewica i Demokraci i w 2015 roku jako Zjednoczona Lewica) oraz PiS. Najsilniejszą redystrybucję proponuje Partia Razem, która chce między innymi wprowadzić mocno progresywną skalę podatkową z progiem $75 \%$ dla dochodów powyżej 500 tys. zł rocznie oraz progresywne opodatkowanie firm. SLD proponuje konsekwentnie zwiększenie progresji podatkowej, podwyższenie płacy minimalnej oraz finansowanie przez państwo budowy mieszkań. Od swojego powstania niezmiennie za pro-

7 W 2015 roku CBOS nie przeprowadził sondażu w listopadzie, wykorzystane zostały zatem wyniki z badania grudniowego, opublikowanego dwa miesiące po wyborach.

8 Za partie liczące się na scenie politycznej uznaliśmy te, które uzyskały w wyborach więcej niż 3\% głosów. 
gresywnymi podatkami opowiadało się też PiS - w programie partii z 2014 roku znajduje się propozycja wprowadzenia trzeciego progu w PIT dla najlepiej zarabiających oraz zwiększenia kwoty wolnej od podatku. Ugrupowanie to proponowało zwiększenie transferów społecznych, w tym obniżenie wieku emerytalnego i wprowadzenie programu świadczeń wychowawczych. Z grupy partii opowiadających się za redystrybucją dochodów wyłączono w badanym okresie Polskie Stronnictwo Ludowe (PSL). Choć program ugrupowania z 2007 roku zawierał postulaty rozszerzania społecznej gospodarki rynkowej, w tym korygowania niesprawiedliwości generowanych przez rynek poprzez progresywne podatki, oraz odrzucał doktrynę neoliberalną, to w latach 2007-2015 PSL postrzegane było jako partia rolnicza (opowiadająca się za wzrostem redystrybucji dochodów na rzecz tej grupy społecznej) oraz potencjalny koalicjant liberalnej gospodarczo Platformy Obywatelskiej. W rezultacie zaliczenie tej partii do ugrupowań redystrybucyjnych mogłoby w naszej ocenie zniekształcić wyniki analizy.

TABELA 2. Łączne poparcie dla partii politycznych opowiadających się za wzrostem redystrybucji dochodów w 2007, 2011 i 2015 roku.

\begin{tabular}{|c|c|c|c|}
\hline Procent głosujących & 2007 & 2011 & 2015 \\
\hline Ogółem oficjalne wyniki & 45 & 38 & 49 \\
\hline Ogółem średnia CBOS & 40 & 28 & 41 \\
\hline \multicolumn{4}{|l|}{ wiek } \\
\hline 15-24 lata & 22 & 22 & 24 \\
\hline 25-34 lata & 38 & 26 & 30 \\
\hline $35-44$ lata & 36 & 27 & 35 \\
\hline 45-54 lata & 40 & 28 & 47 \\
\hline 55-64 lata & 48 & 28 & 52 \\
\hline $65+$ lat & 52 & 35 & 49 \\
\hline \multicolumn{4}{|l|}{ dochód } \\
\hline 1-4 grupa decylowa rozkładu & 35 & 33 & 47 \\
\hline 5-10 grupa decylowa rozkładu & 43 & 26 & 40 \\
\hline \multicolumn{4}{|l|}{ wyksztalcenie } \\
\hline niskie & 44 & 31 & 51 \\
\hline średnie & 38 & 25 & 37 \\
\hline wyższe & 33 & 26 & 31 \\
\hline \multicolumn{4}{|l|}{ miejsce zamieszkania } \\
\hline tereny wiejskie & 38 & 31 & 50 \\
\hline
\end{tabular}




\begin{tabular}{|l|c|c|c|}
\hline Procent głosujących & 2007 & 2011 & 2015 \\
\hline $\begin{array}{l}\text { małe miasta } \\
(2-20 \text { tys. mieszkańców) }\end{array}$ & 41 & 31 & 36 \\
\hline $\begin{array}{l}\text { średnie } \text { i duże miasta } \\
(>20 \text { tys. mieszkańców) }\end{array}$ & 41 & 26 & 34 \\
\hline
\end{tabular}

Źródło: opracowanie własne na podstawie danych CBOS i PKW.

Jak wynika z tabeli 2, poparcie dla partii redystrybucyjnych ulegało w ostatnich latach silnym wahaniom - w 2007 roku zagłosowało na nie 45\% społeczeństwa, w 2012 jedynie 38\% społeczeństwa, a w 2015 roku prawie połowa wszystkich wyborców. Na analogiczne zmiany wskazują również dane CBOS, przy czym sam poziom deklarowanego poparcia partii redystrybucyjnych był we wszystkich zbadanych okresach istotnie niższy, niż wynikałoby to z oficjalnych wyników wyborów. Nawet uwzględniając ten systematyczny błąd, nie da się jednak jasno wskazać, że nastąpił (na poziomie ogólnokrajowym) znaczny wzrost poparcia dla partii redystrybucyjnych, który można byłoby wiązać ze zmniejszeniem akceptacji nierówności dochodowych. Dlatego konieczne było przeprowadzenie analizy zmian poparcia politycznego w poszczególnych grupach społecznych. W związku z powyższym przeanalizowaliśmy poparcie zmiany preferencji wyborczych w czterech wymiarach - pod względem wieku, wykształcenia, miejsca zamieszkania i dochodów wyborców.

$\mathrm{Z}$ analizy wynika, że partie redystrybucyjne generalnie cieszą się ponad dwukrotnie wyższym poparciem u starszych wyborców niż u tych najmłodszych (poniżej 24. roku życia). Warto jednak odnotować stopniowy spadek poparcia dla tych ugrupowań wśród osób w wieku emerytalnym - w 2007 roku popierało je 52\% osób powyżej 65. roku życia, a w 2015 o 3 pp. mniej przy jednoczesnym ogólnym wzroście średniego poparcia partii redystrybucyjnych.

Powyższy rozkład preferencji politycznych wykazuje silną korelację na poziomie makro zarówno z akceptacją nierówności dochodowych, jak i z oceną zasadności nierówności dochodowych (obie wyższe u osób młodych i maleją wraz z wiekiem). Jednakże zmiany percepcji nierówności dochodowych w ostatnich badaniach WVS jedynie w niewielkim stopniu odwzorowują zmiany preferencji wyborczych według grup wiekowych - i choć faktycznie najsilniejszy spadek akceptacji nierówności dochodowych wystąpił w kohorcie wiekowej 45-54 lata, w której zanotowano również najsilniejszy wzrost poparcia dla partii redystrybucyjnych, to kierunek zmian preferencji politycznych i percepcji nierówności dochodowych w wielu kohortach był różny. 
Dobrze widoczna jest korelacja między wielkością miejsca zamieszkania a preferencjami wyborczymi. Mniejsze miasta i wsie zdecydowanie preferuja ugrupowania o profilu redystrybucyjnym. Co więcej, to właśnie na terenach wiejskich miał miejsce największy wzrost poparcia dla tego typu ugrupowań w ostatnich latach. Podobny schemat zmian można było zaobserwować podczas analizy akceptacji nierówności dochodowych - najsilniej spadła ona właśnie na wsiach, a spadek ten był istotny statystycznie przy każdym poziomie istotności. Warto jednak przypomnieć, że to właśnie na terenach wiejskich akceptacja nierówności dochodowych wciąż pozostaje największa wśród wszystkich grup wyborców pod względem miejsca zamieszkania.

Od 2007 roku nie zmieniła się prawidłowość, zgodnie z którą wyższy poziom wykształcenia wyborców przekłada się na niższy odsetek osób głosujących na partie redystrybucyjne. Zróżnicowanie to uległo nasileniu w konsekutywnych wyborach parlamentarnych. Podczas gdy w 2007 roku różnica w poparciu partii redystrybucyjnych u osób z niższym wykształceniem była o 11 pp. wyższa niż u osób z wyższym wykształceniem, to w 2015 roku przewaga ta sięgnęła 20 pp. Podobną tendencję można było zaobserwować w przypadku zmian oceny zasadności nierówności dochodowych, która ulegała stopniowej poprawie wśród osób wysoko wykształconych, a praktycznie nie zmieniła się u osób z niskim wykształceniem. Jednak w przypadku akceptacji nierówności dochodowych wystapiły tendencje odwrotne-zróżnicowanie akceptacji nierówności dochodowych ze względu na wykształcenie uległo zmniejszeniu.

Pomiędzy 2007 a 2015 rokiem nastapiła silna zmiana poparcia partii redystrybucyjnych ze względu na dochód - w 2007 roku cieszyły się one większym o 8 pp. poparciem u osób z wyższymi dochodami (powyżej 4. decyla rozkładu'), a w 2015 roku większym o 7 pp. poparciem u osób z niższymi dochodami. Tak duże zmiany w żaden sposób nie odzwierciedlają zmian w percepcji nierówności dochodowych, które zachodziły stosunkowo równomiernie w różnych grupach dochodowych.

Z powyższej analizy statystycznej nie sposób zatem wyciagnąć jednoznacznego wniosku, czy zaobserwowane zmiany w percepcji nierówności dochodowych miały istotny wpływ na wyniki wyborów parlamentarnych w latach 2007-2015. Wynika to po części z różnic w latach prowadzenia badań, gdyż ankiety WVS były prowadzone w 2005 i 2012 roku, podczas gdy wybory parlamentarne stanowiące

9 Zgodnie z metodyką CBOS jako przybliżoną górną wartość graniczną 4. grupy decylowej rozkładu przyjęliśmy dochód rozporządzalny na osobę w wysokości 500 zł w 2007 roku, 750 zł w 2011 i 1000 zł w 2015. 
przedmiot analizy odbywały się w latach 2007, 2011 i 2015, a po części z mnogości innych czynników wpływających na zmiany preferencji wyborczych Polaków w badanym okresie [Tavits 2005; Turska-Kawa, Wojtasik 2010; Peszyński 2016; Starzyk 2016]. Pojedyncze poczynione powyżej obserwacje wskazująjednak na zasadność dalszych badań w temacie zależności między percepcją nierówności dochodowych a preferencjami wyborczymi, gdyż wskazuja, iż percepcja ta może być istotną determinantą decyzji wyborczych, mimo że zmiany percepcji nie były w badanym okresie silnie skorelowane ze zmianami w poparciu partii politycznych. Zarysowane przeszkody badawcze wymagająjednak zastosowania alternatywnych narzędzi analitycznych - zejścia z poziomu makroanalizy na poziom mikrodanych.

W związku z powyższym ostatnim elementem naszej analizy jest estymacja szeregu równań regresji logistycznej, określających determinanty preferencji politycznych, o następującej postaci:

$$
\operatorname{logit}\left(p_{i}\right)=\alpha+\beta_{1} * a k c_{\mathrm{i}}+\beta_{2} * z a s_{i}+\gamma * \text { rest }_{i}+\varepsilon_{i}
$$

gdzie indeks $i$ oznacza określonego respondenta z badania WVS. Zmienną zależną jest funkcja logitowa warunkowego prawdopodobieństwa $p$, że respondent $i$ popiera daną partię polityczną (odpowiedź na pytanie E179 w ankiecie WVS). Z kolei zmienne akc i zas odzwierciedlają, odpowiednio, poziom akceptacji nierówności dochodowych i ocenę zasadności nierówności dochodowych respondenta (zgodnie z definicją opisaną w sekcji 2).

Uwzględnienie obu zmiennych w jednym równaniu było możliwe ze względu na brak znaczącej współliniowości między nimi w każdym z badanych okresów. Współczynnik korelacji wyniósł 0,06 dla danych z 2005 roku i 0,05 z 2012 roku ${ }^{10}$.

Pozostałe zmienne oznaczone wektorem rest to zmienne kontrolne uwzględnione w badaniu i odpowiadające poszczególnym zmiennym analizowanym w tabeli 1 i 2: wiek respondenta mierzony w latach; dwie zmienne binarne przyjmujące wartość 1 dla, odpowiednio, respondentów z wykształceniem średnim i z wykształceniem wyższym; zmienna binarna przyjmująca wartość 1 dla dochodów powyżej 4. decyla rozkładu oraz dwie zmienne binarne przyjmujące wartość 1 dla, odpowiednio, respondentów z terenów wiejskich (poniżej 2 tys. mieszkańców) i z małych miast (2-20 tys. mieszkańców). Podobnie jak we

10 W ramach analizy stabilności parametrów przeprowadziliśmy dodatkowe estymacje powyższego modelu dla każdej ze zmiennych odzwierciedlających percepcję nierówności dochodowych oddzielnie. Otrzymane wyniki są dostępne na zapytanie u autorów. Nie były one jednak jakościowo różne od tych przedstawionych w tabeli 3. 
wszystkich równaniach regresji logistycznej uwzględniliśmy w równaniu stałą $\alpha$ oraz składnik losowy $\varepsilon$.

Estymację przeprowadziliśmy dla czterech partii, które w obu falach badania WVS popierała wystarczająca liczba respondentów (więcej niż 25), aby wyniki estymacji mogły w sposób dostateczny przybliżać determinanty preferencji politycznych w całej populacji. Tymi partiami były PO, PiS, PSL oraz SLD. Ponadto zbadaliśmy prawdopodobieństwo, czy dany respondent weźmie udział w wyborach oraz przeanalizowaliśmy prawdopodobieństwo, że zagłosuje na partie redystrybucyjne (w tym wypadku wyłącznie PiS i SLD). Wszystkie estymacje przeprowadziliśmy dla dwóch punktów w czasie - osobno dla respondentów badania z 2005 i z 2012 roku. Dzięki temu mogliśmy zbadać nie tylko same determinanty preferencji wyborczych, ale także to, czy uległy one zmianie po globalnym kryzysie finansowym. Wyniki wszystkich estymacji przedstawia tabela 3.

Najważniejszym z punktu widzenia niniejszej analizy rezultatem estymacji jest zaobserwowany między 2005 a 2012 wzrost znaczenia percepcji nierówności dochodowych Polaków dla ich preferencji politycznych. O ile w 2005 roku akceptacja i ocena zasadności nierówności dochodowych nie miały znaczenia przy decyzji o wyborze którejkolwiek z badanych partii, o tyle w 2012 roku ocena zasadności nierówności dochodowych była statystycznie istotną determinantą wyboru między PO a PiS - osoby uważające rozkład dochodów w społeczeństwie za zasadny popierały z większym prawdopodobieństwem $\mathrm{PO}$, a osoby przeświadczone, że dochody nie odzwierciedlają faktycznego wysiłku włożonego w pracę, były bardziej skłonne opowiadać się za PiS.

TABELA 3. Wyniki estymacji modelu regresji logistycznej poparcia wybranych partii politycznych w latach 2005 i 2012.

\begin{tabular}{|c|c|c|c|c|c|c|}
\hline \multirow{2}{*}{ Zmienne niezależne } & \multicolumn{2}{|c|}{ PO } & \multicolumn{2}{c|}{ PiS } & \multicolumn{2}{c|}{ Niegłosujący } \\
\cline { 2 - 7 } & 2005 & 2012 & 2005 & 2012 & 2005 & 2012 \\
\hline $\begin{array}{c}\text { percepcja nierówności } \\
\text { dochodowych }\end{array}$ & & & & & & \\
\hline Akceptacja & $-0,027$ & 0,037 & $-0,013$ & $-0,056$ & $-0,050$ & $-0,021$ \\
\hline & $(0,037)$ & $(0,030)$ & $(0,033)$ & $(0,035)$ & $(0,036)$ & $(0,036)$ \\
\hline Ocena zasadności & 0,006 & $0,074^{* *}$ & $-0,016$ & $-0,0753^{* *}$ & $-0,053$ & 0,002 \\
\hline & $(0,034)$ & $(0,032)$ & $(0,030)$ & $(0,037)$ & $(0,034)$ & $(0,038)$ \\
\hline pozostate zmienne & & & & & & \\
\hline Wiek & $-0,016^{* * *}$ & 0,003 & 0,005 & $-0,002$ & $-0,0106^{*}$ & $-0,0241^{* * *}$ \\
\hline & $(0,006)$ & $(0,005)$ & $(0,005)$ & $(0,006)$ & $(0,006)$ & $(0,007)$ \\
\hline
\end{tabular}


PERCEPCJA NIERÓWNOŚCI DOCHODOWYCH A POPARCIE POLSKICH PARTII...

\begin{tabular}{|c|c|c|c|c|c|c|}
\hline \multirow{2}{*}{ Zmienne niezależne } & \multicolumn{2}{|c|}{$\mathrm{PO}$} & \multicolumn{2}{|c|}{ PiS } & \multicolumn{2}{|c|}{ Niegłosujący } \\
\hline & 2005 & 2012 & 2005 & 2012 & 2005 & 2012 \\
\hline \multicolumn{7}{|l|}{ Wykształcenie: } \\
\hline \multirow[t]{2}{*}{ średnie } & $-0,211$ & $-0,363$ & $-0,037$ & $0,737 * *$ & $-0,016$ & $0,873 * * *$ \\
\hline & $(0,279)$ & $(0,293)$ & $(0,244)$ & $(0,296)$ & $(0,286)$ & $(0,315)$ \\
\hline \multirow[t]{2}{*}{ wyższe } & $-0,286$ & $-0,089$ & 0,216 & 0,369 & 0,185 & $0,772 * * *$ \\
\hline & $(0,215)$ & $(0,230)$ & $(0,193)$ & $(0,258)$ & $(0,211)$ & $(0,256)$ \\
\hline \multirow[t]{2}{*}{ Dochód } & $0,328^{*}$ & $0,313^{*}$ & 0,031 & $-0,557 * * *$ & $-0,035$ & $-0,371^{*}$ \\
\hline & $(0,194)$ & $(0,185)$ & $(0,179)$ & $(0,216)$ & $(0,200)$ & $(0,225)$ \\
\hline \multicolumn{7}{|l|}{ Miejsce zamieszkania: } \\
\hline \multirow[t]{2}{*}{ tereny wiejskie } & $-0,241$ & $-0,685 * * *$ & $-0,306$ & 0,325 & $-0,007$ & $-0,241$ \\
\hline & $(0,212)$ & $(0,203)$ & $(0,191)$ & $(0,234)$ & $(0,212)$ & $(0,235)$ \\
\hline \multirow[t]{2}{*}{ male miasta } & $-0,107$ & $-0,326$ & 0,143 & 0,449 & 0,032 & $-1,008 * *$ \\
\hline & $(0,269)$ & $(0,290)$ & $(0,241)$ & $(0,329)$ & $(0,268)$ & $(0,493)$ \\
\hline \multirow[t]{2}{*}{ Stała } & 0,008 & $-1,023^{* *}$ & $-0,375$ & $-0,517$ & $-0,414$ & $-0,463$ \\
\hline & $(0,435)$ & $(0,432)$ & $(0,395)$ & $(0,502)$ & $(0,427)$ & $(0,500)$ \\
\hline \multicolumn{7}{|l|}{ statystyki } \\
\hline $\begin{array}{l}\text { Liczba obserwacji } \\
(\text { w tym } y=1)\end{array}$ & $619(190)$ & $564(230)$ & $619(282)$ & $564(134)$ & $772(163)$ & $693(116)$ \\
\hline $\begin{array}{l}\text { Statystyka Chi2 } \\
\text { (prawd.) }\end{array}$ & 0,01 & 0,00 & 0,54 & 0,00 & 0,30 & 0,00 \\
\hline Pseudo R2 & 0,03 & 0,04 & 0,01 & 0,06 & 0,01 & 0,05 \\
\hline
\end{tabular}

W nawiasach podano błędy standardowe estymacji.

$* * * \mathrm{p}<0.01, * * \mathrm{p}<0.05, * \mathrm{p}<0.1$

Źródło: opracowanie własne.

TABELA 3. (cd.) Wyniki estymacji modelu regresji logistycznej poparcia wybranych partii politycznych w latach 2005 i 2012.

\begin{tabular}{|c|c|c|c|c|c|c|}
\hline \multirow{2}{*}{ Zmienne niezależne } & \multicolumn{2}{|c|}{ PSL } & \multicolumn{2}{c|}{ SLD } & Partie redystrybucyjne \\
\cline { 2 - 7 } & 2005 & 2012 & 2005 & 2012 & 2005 & 2012 \\
\hline $\begin{array}{c}\text { percepcja nierówności } \\
\text { dochodowych }\end{array}$ & & & & & & \\
\hline Akceptacja & 0,015 & 0,022 & $-0,001$ & $-0,023$ & $-0,012$ & $-0,055^{*}$ \\
\hline & $(0,080)$ & $(0,052)$ & $(0,061)$ & $(0,043)$ & $(0,032)$ & $(0,030)$ \\
\hline Ocena zasadności & 0,046 & 0,061 & 0,067 & $-0,061$ & 0,003 & $-0,085^{* * *}$ \\
\hline & $(0,074)$ & $(0,055)$ & $(0,057)$ & $(0,047)$ & $(0,030)$ & $(0,032)$ \\
\hline
\end{tabular}




\begin{tabular}{|c|c|c|c|c|c|c|}
\hline \multirow{2}{*}{ Zmienne niezależne } & \multicolumn{2}{|c|}{ PSL } & \multicolumn{2}{|c|}{ SLD } & \multicolumn{2}{|c|}{ Partie redystrybucyjne } \\
\hline & 2005 & 2012 & 2005 & 2012 & 2005 & 2012 \\
\hline \multicolumn{7}{|l|}{ pozostale zmienne } \\
\hline \multirow[t]{2}{*}{ Wiek } & $0,033 * *$ & $0,028 * * *$ & $0,016^{*}$ & $0,023 * * *$ & $0,009 *$ & $0,010^{*}$ \\
\hline & $(0,013)$ & $(0,011)$ & $(0,009)$ & $(0,008)$ & $(0,005)$ & $(0,006)$ \\
\hline \multicolumn{7}{|l|}{ Wykształcenie: } \\
\hline \multirow[t]{2}{*}{ średnie } & $-0,766$ & 0,581 & 0,069 & $-1,056^{* *}$ & 0,011 & 0,141 \\
\hline & $(0,606)$ & $(0,452)$ & $(0,394)$ & $(0,474)$ & $(0,240)$ & $(0,276)$ \\
\hline \multirow[t]{2}{*}{ wyższe } & $-0,154$ & $1,193 * * *$ & $-1,244 * *$ & $-0,981 * *$ & $-0,039$ & $-0,136$ \\
\hline & $(0,505)$ & $(0,378)$ & $(0,503)$ & $(0,407)$ & $(0,192)$ & $(0,235)$ \\
\hline \multirow[t]{2}{*}{ Dochód } & 0,004 & 0,358 & $-0,687^{*}$ & 0,423 & $-0,144$ & $-0,216$ \\
\hline & $(0,468)$ & $(0,341)$ & $(0,361)$ & $(0,278)$ & $(0,177)$ & $(0,188)$ \\
\hline \multicolumn{7}{|l|}{ Miejsce zamieszkania: } \\
\hline \multirow[t]{2}{*}{ tereny wiejskie } & $2,550 * * *$ & $2,214 * * *$ & $-0,400$ & 0,0988 & $-0,398 * *$ & 0,287 \\
\hline & $(0,642)$ & $(0,446)$ & $(0,370)$ & $(0,296)$ & $(0,187)$ & $(0,204)$ \\
\hline \multirow[t]{2}{*}{ mate miasta } & 1,323 & 0,868 & $-0,301$ & $-0,064$ & 0,0701 & 0,300 \\
\hline & $(0,834)$ & $(0,659)$ & $(0,482)$ & $(0,429)$ & $(0,241)$ & $(0,294)$ \\
\hline \multirow[t]{2}{*}{ Stała } & $-6,588 * * *$ & $-6,267 * * *$ & $-2,971 * * *$ & $-2,592 * * *$ & $-0,193$ & $-0,325$ \\
\hline & $(1,237)$ & $(0,966)$ & $(0,750)$ & $(0,642)$ & $(0,391)$ & $(0,437)$ \\
\hline \multicolumn{7}{|l|}{ statystyki } \\
\hline $\begin{array}{l}\text { Liczba obserwacji } \\
(\mathrm{w} \text { tym } \mathrm{y}=1)\end{array}$ & 619 (27) & $564(51)$ & 619 (47) & $564(74)$ & 619 (329) & $564(208)$ \\
\hline $\begin{array}{l}\text { Statystyka Chi2 } \\
\text { (prawd.) }\end{array}$ & 0,00 & 0,00 & 0,01 & 0,00 & 0,25 & 0,00 \\
\hline Pseudo R2 & 0,15 & 0,18 & 0,06 & 0,05 & 0,01 & 0,03 \\
\hline
\end{tabular}

W nawiasach podano błędy standardowe estymacji.

$* * * \mathrm{p}<0.01, * * \mathrm{p}<0.05, * \mathrm{p}<0.1$

Źródło: opracowanie własne.

Percepcja nierówności dochodowych nie miała natomiast statystycznie istotnego wpływu na decyzje o wyborze PSL i SLD w obu badanych okresach. W przypadku tych partii dużo większe znaczenie miały wiek, miejsce zamieszkania (PSL) czy poziom wykształcenia. Również w przypadku analizy decyzji o samej partycypacji wyborczej zmienne mierzące percepcję nierówności dochodowych okazały się zupełnie nieistotne.

Warto zauważyć, że przy łącznej analizie respondentów głosujących w 2012 roku na PiS lub SLD (partie redystrybucyjne) błędy standardowe 
oszacowań parametrów stojących przy obu zmiennych mierzących percepcję nierówności dochodowych są niższe niż w przypadku analizy respondentów głosujących wyłącznie na PiS lub SLD. Tym samym wpływ zarówno akceptacji, jak i oceny nierówności dochodowych na prawdopodobieństwo poparcia partii redystrybucyjnych był w 2012 roku wyższy niż w przypadku analizy poparcia którejkolwiek z tych partii z osobna. Ponadto parametr stojący przy akceptacji nierówności dochodowych był ujemny i istotnie różny od zera (przy przyjęciu $10 \%$ poziomu istotności), co wskazuje, że ten pogląd odgrywał ważną, choć drugorzędną rolę przy określaniu preferencji politycznych. Oznacza to, że o ile na wybór PiS lub SLD wpływa bardzo wiele innych czynników, które są ważniejsze niż stosunek Polaków do nierówności dochodowych, o tyle w przypadku decyzji, czy głosować na partie o liberalnym programie gospodarczym, czy też na te opowiadające się za wzrostem opodatkowania najbogatszych i zwiększeniem wysokości świadczeń socjalnych, rosnące znaczenie ma ocena zasadności nierówności dochodowych i - w mniejszym stopniu - ich akceptacja.

Co więcej, zmienne mierzące percepcję nierówności dochodowych były poza wiekiem jedynymi istotnymi statystycznie determinantami prawdopodobieństwa poparcia partii redystrybucyjnych. Wskazuje to, że niezależnie od wykształcenia, dochodu czy miejsca zamieszkania osoby o niższej akceptacji i gorszej ocenie zasadności nierówności dochodowych były w 2012 roku bardziej skłonne głosować na partie redystrybucyjne. To ewidentna zmiana w porównaniu z $2005 \mathrm{roku}$, kiedy percepcja nierówności dochodowych nie miała żadnego znaczenia dla preferencji wyborczych, a linie podziałów politycznych w społeczeństwie przebiegały względem zupełnie innych linii demarkacyjnych. Tłumaczy to przynajmniej częściowo, dlaczego nie udało się zaobserwować w analizie statystycznej na danych zagregowanych korelacji pomiędzy zmianami percepcji nierówności dochodowych a zmianami poparcia partii redystrybucyjnych.

Analizując wyniki estymacji, należy zwrócić uwagę na niski współczynnik determinacji (pseudo- $\mathrm{R}^{2}$ ) charakteryzujący praktycznie wszystkie oszacowane modele dla poszczególnych partii politycznych. To przede wszystkim rezultat dużej liczby obserwacji i samej postaci regresji, która z definicji wymusza pewne niedopasowanie modelu do danych. Oszacowywane jest bowiem prawdopodobieństwo wystąpienia zdarzenia, a nie określona wartość zmiennej zależnej, jak w przypadku regresji liniowych. Dlatego w modelach logistycznych na dużej próbie wartość współczynnika determinacji na poziomie $0,2-0,3$ uznawana jest już za wysoką. Mimo to większość modeli ma współczynniki determinacji istotnie niższe od tego przedziału, a w części przypadków jest on zbliżony do zera. 
Jedyny wyjątek stanowią modele opisujące prawdopodobieństwo poparcia dla PSL, które cechuje wartość statystyki pseudo- $\mathrm{R}^{2}$ zbliżona do tych uznawanych za wysokie. To rezultat stosunkowo dużej homogeniczności wyborców PSL. Są to zazwyczaj osoby starsze, z terenów wiejskich i o relatywnie wyższym wykształceniu. Wskazują na to bardzo wysokie istotności parametrów stojących przy tych zmiennych.

Ze względu na niski poziom współczynnika determinacji zdecydowaliśmy się zatem oszacować dodatkowo statystykę $\chi^{2}$, która lepiej mierzy, czy uwzględnione regresanty mają (łącznie) istotny wpływ na zmienną zależną. W tabeli 3 podaliśmy wyliczone na podstawie statystyki $\chi^{2}$ prawdopodobieństwo, że zmienne niezależne faktycznie objaśniają poparcie dla poszczególnych partii politycznych. Z przedstawionych danych wynika, że w zdecydowanej większości przypadków dokonany wybór regresantów jest zasadny przy dowolnym poziomie istotności. Co warto odnotować, we wszystkich przypadkach statystyka $\chi^{2}$ jest wyższa dla oszacowań na próbie z 2012 roku niż na próbie z 2005 roku, i to głównie za sprawą niższych błędów standardowych estymacji parametrów stojących przy zmiennych mierzących percepcję nierówności dochodowych. Stanowi to kolejną przesłankę, że różnice w podejściu do zróżnicowania dochodów zaczęły po globalnym kryzysie finansowym odgrywać istotną rolę przy kształtowaniu się preferencji wyborczych Polaków. Wciąż jednak niskie statystyki pseudo- $\mathrm{R}^{2}$ i w niektórych przypadkach $\chi^{2}$ pokazują, że przyjęty zestaw zmiennych niezależnych odzwierciedla jedynie niewielką część czynników wpływających na preferencje polityczne Polaków. Istnieje bowiem szereg innych postaw społecznych, opisanych szczegółowo we wcześniejszych badaniach [Cześnik 2014; Turska-Kawa, Wojtasik 2010; Peszyński 2016], które mają wpływ na decyzje wyborcze, a które w niniejszej analizie nie zostały uwzględnione. Dlatego opisane powyżej wyniki należy traktować jedynie jako kolejną przesłankę świadczącą o rosnącym znaczeniu percepcji nierówności dochodowych dla preferencji politycznych, a nie jako pełen opis determinant poparcia dla poszczególnych partii.

\section{PODSUMOWANIE}

Powyższa analiza pokazuje, że stosunek Polaków do nierówności dochodowych nabiera coraz większego znaczenia dla ich preferencji wyborczych. Tym samym odnotowany w ostatnich wyborach parlamentarnych wzrost poparcia dla PiS, ale także łącznego poparcia dla wszystkich partii redystrybucyjnych (w tym Zjednoczonej Lewicy i nowo powstałej Partii Razem), może być przynajmniej w części przypisany naciskowi, jaki położyły one w swoim programie na zwięk- 
szenie świadczeń socjalnych finansowanych z podatków od osób najbogatszych i dużych przedsiębiorstw, a także na wyrównywanie szans osób najbiedniejszych w rywalizacji zarówno na rynku pracy, jak i na rynku produktu. Efekt ten mógł być wzmocniony przez stopniowy spadek akceptacji nierówności dochodowych po globalnym kryzysie finansowym, zwłaszcza wśród osób z wyższym wykształceniem. Przejawiało się to zapewne w odpływie elektoratu z PO do niektórych ugrupowań redystrybucyjnych, zwłaszcza Partii Razem.

Równocześnie należy zauważyć, że wprowadzone przez rząd PiS reformy w polityce socjalnej [Rapacki, Czerniak 2018], mające na celu zwiększenie redystrybucji dochodów przez państwo, przełożyły się na utrzymanie wysokiego poparcia PiS w latach 2016-2017, i to mimo licznych problemów wizerunkowych tej partii - od konfliktu z Unią Europejską przez wypłaty wysokich nagród dla ministrów aż po zwiększenie zależności sądów od władzy ustawodawczej i wykonawczej. Jak pokazują badania [Graca-Gelert 2018], wprowadzenie programu wypłat świadczeń wychowawczych (tzw. program Rodzina 500+) stanowiło jedną z przyczyn spadku współczynnika Giniego w Polsce z 0,322 w 2015 roku do 0,304 w 2016 i 0,298 w 2017. Tym samym rząd spełnił w dużej części swoje redystrybucyjne obietnice wyborcze, co przy utrzymaniu wysokiego znaczenia percepcji nierówności dochodowych dla preferencji politycznych w kolejnych latach będzie sprzyjało utrzymaniu wysokiego poparcia dla PiS.

Powyższa analiza jest jedynie przyczynkiem do badania zależności między percepcją nierówności dochodowych a preferencjami politycznymi. Niedoskonałość wykorzystanych mierników, niskie współczynniki determinacji otrzymanych modeli oraz brak danych dla postaw społecznych po 2012 roku każą podchodzić do otrzymanych rezultatów z rezerwą. Konieczne jest zatem prowadzenie dalszych prac badawczych w tym zakresie, w tym przeprowadzenie lepiej dopasowanych do celów analizy badań ankietowych, które pozwolą na weryfikację hipotezy o istotnym wpływie percepcji nierówności dochodowych na preferencje polityczne Polaków.

\section{BIBLIOGRAFIA}

Alesina Alberto, Rafael Di Tella, Robert MacCulloch. 2004. "Inequality and happiness: are Europeans and Americans different?". Journal of Public Economics 88(9-10): 2009-2042.

Brzezinski Michal, Barbara Jancewicz, Natalia Letki. 2013. Growing inequalities and their impacts in Poland. http://archive.uva-aias.net/uploaded_files/publications/Poland.pdf [dostęp: 13.09.2017].

CBOS. 2017. Stosunek Polaków do nierówności społecznych. Komunikat z Badań nr 85/2017. Warszawa: CBOS. 
Czerniak Adam, Patrycja Graca-Gelert. 2016. Inequality and growth in a panel of countries. Does perception matter? Badanie statutowe Kolegium Gospodarki Światowej. Szkoła Główna Handlowa w Warszawie.

Czerniak Adam, Patrycja Graca-Gelert. 2017. Kształtowanie się percepcji nierówności dochodów w Polsce w latach 1989-2012. Badanie statutowe Kolegium Gospodarki Światowej. Szkoła Główna Handlowa w Warszawie.

Cześnik Mikołaj. 2014. Zachowania wyborcze a zmienne socjodemograficzne: doświadczenia PGSW. W: Segmentacja, targeting, pozycjonowanie na rynku politycznym, M. Cichosz, D. Skrzypiński (red.), 34-43. Wrocław: Towarzystwo Edukacji Obywatelskiej.

Domański Henryk, Zbigniew Sawiński. 2012. „Sprawiedliwe nierówności zarobków”. Studia Socjologiczne 3(206): 7-27.

Engelhardt Andreas, Carina Wagener. 2014. "Biased perceptions of income inequality and redistribution". CESifo Working Papers 4838.

Graca-Gelert Patrycja. 2016. "Household income inequality in Poland from 2005 to 2013 - A decomposition of the Gini coefficient by socio-economic groups". Nierówności Społeczne a Wzrost Gospodarczy 47(3): 427-441.

Graca-Gelert Patrycja. 2018. "Income inequality and poverty in Poland in 2010-2016 with particular focus on aspects of urbanization". W: Poland: Report on competitiveness 2018. The role of cities in creating competitive advantages, M. Weresa (red.), 43-62. Warszawa: Oficyna Wydawnicza SGH.

Grosfeld Irena, Claudia Senik. 2010. “The emerging aversion to inequality. Evidence from subjective data”. Economics of Transition 18(1): 1-26.

GUS. 2017. „Budżety gospodarstw domowych w 2016 r.”. Informacje i Opracowania Statystyczne. http://www.worldvaluessurvey.org/wvs.jsp [dostęp: 7.12.2017].

https://www.europeansocialsurvey.org/docs/round8/survey/ESS8_data_documentation_report e02_0.pdf [ dostęp: 30.08.2018].

Jasiecki Krzysztof. 2010. Deficit merytokracji i legitymizacja władzy politycznej. W: Legitymizacja w Polsce. Nieustajacy kryzys w zmieniajacych się warunkach?, A. Rychard, H. Domański (red.), Wydawnictwo IFiS PAN, Warszawa.

Karpiński Zbigniew. 2010. "Legitimacy of inequality and the stability of income distributions in Poland". Centre for Comparative Economics, Economics Working Paper 107.

Kelley Jonathan, Krzysztof Zagórski. 2005. "Economic change and the legitimation of inequality: the transition from socialism to the free market in Central-East Europe". Research in Social Stratification and Mobility 22: 321-366.

Kołczyńska Marta, Joseph J. Merry. 2013. "Change in preferred levels of income inequality: Poland, 1988-2003”. http://takaecon.sixcore.jp/20thIPDC_web/All/2_4.2.3_Kolczynska/ Paper.pdf [dostęp: 13.09.2017].

Miernik Rafal. 2018. "Reformy Prawa i Sprawiedliwości - nowy kierunek rozwoju państwa czy skuteczna strategia wyborcza?". Studia Politicae Universitatis Silesiensis 20: 99-116.

Niehues Judith. 2014. "Subjective perceptions of inequality and redistributive preferences: an international comparison". IW-TRENDS Discussion Papers 2.

Peszyński Wojciech. 2016. „Prezydencjalizacja zachowań wyborczych w elekcji parlamentarnej w 2015 roku". Political Preferences 12: 37-55.

Rapacki Ryszard, Adam Czerniak. 2018. Directions of economic policy and the most significant challenges in 2010-2017. W: Poland: Report on competitiveness 2018. The role of cities 
in creating competitive advantages, $\mathrm{M}$. Weresa (red.), 105-120. Warszawa: Oficyna Wydawnicza SGH.

Schneider Simone M. 2012. "Income inequality and its consequences for life satisfaction: what role do social cognitions play?". Social Indicators Research 106(3): 419-438.

Starzyk Adam. 2016. "Kryzys imigracyjny a sytuacja partii prawicowych w Grupie Wyszehradzkiej w 2015 roku”. Wrocławskie Studia Politologiczne 20: 109-123.

Tavits Margit. 2005. "The development of stable party support: Electoral dynamics in postcommunist Europe”. American Journal of Political Science 49(2): 283-298.

Turska-Kawa Agnieszka, Waldemar Wojtasik (red.). 2010. Preferencje polityczne 2009. Postawy-identyfikacje-zachowania. Katowice: UNIKAT 2.

Wysienska-Di Carlo Kinga, Matthew Di Carlo. 2014. "Attitudes towards redistribution and the welfare state in Poland”. http://polpan.org/wp-content/uploads/2014/05/Inequalities_English_summary_reviewed_and_updated.pdf [dostęp: 15.09.2017].

\author{
Adam Czerniak \\ Patrycja Graca-Gelert \\ Ryszard Łuczyn
}

\title{
INCOME INEQUALITY PERCEPTION AND SUPPORT FOR POLISH POLITICAL PARTIES DURING THE PERIOD 2007-2015
}

Summary

The article discusses the relationship between the perception of income inequalities and the political preferences of Poles between the 2007 and 2015 parliamentary elections. Changes in the acceptance and assessed fairness of income inequalities are examined. The impact of these changes on political preferences, in particular, the support of parties advocating an increase in the redistribution of income, is evaluated with statistical analysis on aggregated data and econometric analysis at a micro level. The analysis reveals that the perception of income inequalities, and especially the assessment of their fairness, became an important determinant of Poles' electoral decisions after the global financial crisis. People who assessed income inequalities as unfair and too high became more eager to vote for parties that supported the redistribution of income.

Keywords: parliamentary elections, perception of income inequality, political parties 